\title{
EQUiLIBRIUM
}

Quarterly Journal of Economics and Economic Policy

2015 VOLUME 10 ISSUE 2, June

p-ISSN 1689-765X, e-ISSN 2353-3293

www.economic-policy.pl

Norek, T. \& Arenhardt, D. L. (2015). Comparative Analysis of Innovative Activity Determinants in Selected SME's in Brazil and Poland. Results of Empirical Researches. Equilibrium. Quarterly Journal of Economics and Economic Policy, 10(2), pp. 157-181, DOI: http://dx.doi.org/10.12775/ EQUIL.2015.018

Tomasz Norek ${ }^{*}$ University of Szczecin, Poland Daniel Luis Arenhardt

Federal University of Santa Maria, Brazil

\section{Comparative Analysis of Innovative Activity Determinants in Selected SME's in Brazil and Poland. Results of Empirical Researches}

JEL Classification: $O 1 ; 030 ; 050 ; 057$

Keywords: innovative SMEs; determinants of innovation activity; SMEs in Brazil and Poland

\begin{abstract}
The basic goal of this article is an attempt to conduct comparative analysis of innovation determinants in companies of small and medium enterprises sector in Brazil and Poland. The comparison shall enable an evaluation of which determinants stimulate and which are barriers to innovativeness development in the SME sector in the researched countries. Additionally, such comparison shall indicate if, and in what way, the economical potentials, cultural differences and different historical conditions of the economic development of the researched countries influence the determinants of the innovative activity of the SME sector.
\end{abstract}

(C) Copyright Institute of Economic Research \& Polish Economic Society Branch in Toruń Date of submission: December 12, 2014; date of acceptance: May 6, 2015

* Contact: norek@wzieu.pl, darenhardt@gmail.com, University of Szczecin, ul. Cukrowa 8, 71004 Szczecin, Poland; Federal University of Santa Maria, Avenida Roraima, 1000 - Camobi, Santa Maria - RS, 97105-900, Brazil 
The Authors put forward the following research hypothesis: H1: The determinants forming the innovative potential are similar for Brazilian and Polish companies of SME sector.

In order to examine the hypothesis, the Authors have browsed the world literature on the subject of innovative actions determinants in companies with a special consideration of SME sector companies, they have presented the present condition of innovativeness in SME sector companies in Brazil and Poland (an Internet questionnaire has been used in the research) and they have conducted own empirical research on the determinants influencing the innovativeness level. The received results have been subject to basic statistical comparative analysis and on this basis with the logical induction the Authors have made conclusions on the determinants of innovative activity in researched companies

The article includes the results of all the empirical research conducted by the Authors in the years 2009-2013, and generally available data considering the innovativeness level in the researched countries.

\section{Introduction}

The basic goal of this article is an attempt to conduct a comparative analysis of innovation determinants in companies of small and medium enterprises sector in Brazil and Poland. The comparison shall enable evaluation which determinants stimulate and which are barriers to innovativeness development in the SME sector in the researched countries. Additionally, such comparison shall indicate if and in what way the economical potentials, cultural differences and different historical conditions of the economic development of the researched countries influence the determinants of the innovative activity of the SME sector.

Simultaneously, it needs to be stressed that this article does not intend to identify directly the innovativeness determinants in relation to the companies of SME sector operating in Brazil and Poland.

The economies of Brazil and Poland are characterized by different regional and historical development conditions. Brazil has the seventh largest economy in the world1 and the largest economy in South America. It is considered a rising market and many analysts give it prospects of becoming the world's fourth economy (next to China, India and the United States)2. The economy of Brazil is mainly based on services and the exploitation of natural resources (grains, oil, gas, coal, iron ore, etc.).

\footnotetext{
${ }^{1}$ Country Comparison: GDP (purchasing power parity) (The World Factbook. CIA, 24.02.2013).

${ }^{2}$ Larry Elliott: GDP projections from PwC: how China, India and Brazil will overtake the West by 2050 . The Guardian (14.03.2013).
} 
The economy of Poland, in scope of GDP, is the sixth economy in the European Union and the 20th economy in the world. The economy of Poland is still an economy of mix-ownership nature: within the last twenty years it has been transformed from the centrally controlled economy (socialist) into market economy. Privatization of the vast majority of small and medium State companies and a new liberal law considering the establishment of companies has enabled the construction of the private sector of the economy, which is presently the main motor of the economy in Poland. The Poland's economy is of balanced nature (the ratio of the production sector to the service sector). However, within the last years the sector of services has been developing rapidly.

Despite obvious differences considering the potentials of both economies and the differences in regional social and cultural conditions - both countries have a relatively low innovativeness level. This applies to both total economy and to the activity of the companies from the SME sector.

Summary Innovation Index, the indicator calculated each year by the European Commission for the Union member countries and for 10 nonmember countries, in case of Brazil and Poland is on a low level, especially in comparison with the Index leaders (EC EUROPA, 2014).

It should be stressed here that both Brazil and Poland are at the beginning of the development process based on the increase of innovativeness and competitiveness of own economies and thus there is a long way between them and the competitiveness leaders in the world aspect (or the European innovativeness leaders in case of Poland). According to the experts, economic and social potentials of Brazil and Poland indicate that the innovativeness should increase dynamically in the countries. That is why it seems crucial to research the determinants of companies' innovative operation and specify the factors stimulating the innovativeness and those that block its development. Additionally, conducting the research for the companies of SME sector is exceptionally important since the innovative activeness of the SME sector companies is not registered in detail by the state statistical offices in Brazil and in Poland (they only register the innovative activeness of the companies classified as medium and big) - the research provide important data enabling making conclusions on the innovativeness of this exceptionally important sector of economy.

The outcomes of the research shall help in revealing strong and weak points of the innovative activeness of the SME sector companies of the researched countries and in the long run they shall indicate the ones conditioned by regional factors, typical for the economy of the given country. The undertaken actions are the result of a common initiative of the researchers from Szczecin University (Poland) and Santa Maria Federal Uni- 
versity (Brazil). The cooperation includes the research on the innovativeness of the SME sector companies.

Starting the implementation of the research the Authors put forward the following research hypothesis: (H1): The determinants forming the innovative potential are similar for Brazilian and Polish companies of SME sector.

In order to examine the hypothesis, the Authors have browsed the world literature on the subject of innovative actions determinants in companies with a special consideration of SME sector companies, they have presented the present condition of innovativeness in SME sector companies in Brazil and Poland and they have conducted own empirical research on the determinants influencing the innovativeness level. The article includes the results of all pieces of empirical research conducted by the Authors in the years 2009-2013 and generally available data considering the innovativeness level in the researched countries.

\section{Determinants of Innovative Activity of SMEs. Review of the Literature}

All over the world small and medium enterprises (SME) play the key role in forming economies. The literature presents the general opinion that the balanced development of SME sector is crucial for the economy and is an obligatory condition for the economic growth. Among others, it is caused by the following:

- SME generate over $60 \%$ of new employments.

- SME enable transformation of the industry form traditional production forms to advanced technologies (Dibrell et al., 2008, pp. 203-218; Freel, 2003, pp. 751-770; Audretsch, 2001, pp. 37-51).

- SME of the sector significantly contribute to the development of the global market (Salvato et al., pp. 282-305, 2007; Acedo \& Florin, 2006, pp. 49-67; Karagianni \& Labriandis, 2001, pp. 5-29; Lituchy \& Rail, 2000, pp. 86-97).

- SME play a key role in the development of innovations aiming at the increase of the competitiveness (Low \& Chapman, 2007, pp. 878-891; Audretsch, 2001, p. 37-51).

The issue and importance of the innovativeness in the processes of forming competitiveness of companies is presently beyond question. This aspect, supported by numerous pieces of research, is widely elaborated in the literature on the subject (Janasz \& Kozioł, 2007). The changes taking place in the modern global economy and the increasing complexity and unpredictability of the environment impose on the companies continuous 
search for new ways of ensuring competitive advantage. One of the methods is to introduce innovations, which has become a domain of not only big companies, but also of the SME sector companies. In this aspect, the efficient innovative activity plays a key role in the development of SME sector companies, and consequently also in the development of all national economies.

The literature on the subject includes a wide elaboration of the issue of innovative activity's determinants - both in case of big companies and the companies of SME sector.

Companies' ability to create innovations is generally described as the innovative ability or innovative potential (see Fagerberg, 2004).

The innovation of a given country's economy is mainly determined by the innovation of companies that operate in the economy. The innovation of the companies is influenced by internal factors (including, above all, potential and resources of a company, plus intellectual capital, material, financial and organizational resources). Additionally, the development of enterprise innovation abilities is influenced by the particulars of the industry and sector, where the company operates and external factors (including national conditions [e.g., legal regulations related to innovation support activities] and region-specific conditions [e.g., legal, culture, economic and technical factors]) (Jasiński, 2004, pp. 45-63).

An analysis of all of the modern models of enterprise innovation (see Norek, 2012, pp. 77-84; Tidd \& Bessant 2011) and research on the scope of innovation determinants (Lager, 2011) reveals that the key factor that regulates efficiency in the innovation processes is internal the enterprises' innovation potential.

The theory of innovation potential is based on the concept of company resources. This concept, developed at the beginning of the 1990s, assumes that a company's ability to develop all of the aspects of activity is closely related to the possessed resources. Edith Penrose (1959) was an early proponent of this outlook. Her publications have revealed the role of resources in the formation of company competitive advantage and the increase theory (Hall \& Rosenberg, 2010).

A detailed analysis of the factors that determine company innovation potential is subject to numerous studies and scientific publications. It seems that the most global view of the factors that determine company innovation potential was suggested by Birchall \& Armstrong (2001, pp. 37-45), who created a model of innovation conditions that includes the following factors: external environment, internal environment, innovation process, and development management. 
A similar opinion was presented by McCosh et al. (1998, pp. 175-193), who analyzed the wish list of company managerial staffs and listed conditions required for the effective realization of the innovation processes: culture supporting innovation, creativity enforced by the market, the will and ability to learn, and the ability to profit from company's competences to conduct innovation processes.

Tidd et al. (2001) held a somewhat different view of innovation determinants, and focused in particular on internal organizational factors that stimulate the innovation processes. The most important include, among others: visionary leadership, appropriate organizational structure, recruitment, the willingness to engage in the innovation process, ability to conduct teamwork or the readiness to learn and adopt new solutions.

A comprehensive concept of innovation potential factors was presented by Gloet \& Samson (2013). They pointed out, among other: strategy, leadership, change, customer focus, pro-innovative organizational culture, knowledge alliances, quality processes, learning and innovative HR orientation.

In the Polish literature, the analysis has been presented, among others, in works by Białoń (2010), Poznańska (1998) and Żołnierski (2005).

The most precise seems to be the interpretation suggested by Żołnierski (2005), who suggested that a company's innovation potential is determined by the internal innovation potential as well as the access to external sources of information necessary for the innovation process. According to Żołnierski, the internal innovation potential includes, among others:

- company staff (knowledge, experience, qualifications, competencies and the method of managing available resources),

- research and development (separate research and development units, research and development work, outsourced work and the research and development work conducted with other companies or institutions), and

- applied technologies (IT technologies, machines, equipment and the related innovation level).

Summing up, innovation ability or potential determine a company's ability to create innovations (see Żolnierski, 2005). By analogy, it may be stated that the lack of innovation potential is a barrier to the companies' effective innovation processes.

In addition to the definition of the essence and the role of innovation potential in the innovation process, an issue is the measurement of individual determinants of innovation potential.

A considerable part of factors that significantly affect the innovative capacity of a company (particularly as related to external factors) are difficult 
to measure or to quantify which, to a large extent, makes it difficult to analyze and evaluate these issues precisely (see Mangiarotti \& Mention, 2014; Fagerberg, 2004).

A company, in practice, can influence only internal factors in the process of conscious formation of innovative capacity and the creation of a strategy related to innovative activity for the long term. For this reason, the ability to analyze and evaluate internal factors that constitute enterprise innovative capacity has become extremely important. Recently, discussions about the determinants that affect enterprise innovativeness and methods of innovativeness measurement have gained significant meaning. This discussion, supported by numerous publications, has both the academic and practical dimension, as it is economic practice that is remarkably interested in effective tools for the measurement and evaluation of innovative capacity and the effectiveness of innovative processes that occur in companies (see Cooke, 2011; Prahalad \& Krishnam, 2011). Large enterprises have developed efficient methods and tools used for practical evaluation of the own innovative capacities (Tidd \& Bessant, 2011). Examples of such tools are innovativeness audits conducted in enterprises, innovativeness benchmarking or measures included in balanced results cards (BCS; McKeown, 2008). In the case of SME companies, the analysis and evaluation of the determinants of innovative potential, because of less data availability, is definitely more difficult.

The indicated multisidedness and complexity of the phenomena that form the innovative capacity of enterprises forces one to search for optimum methods by which to analyze and evaluate this area. This problem particularly applies to SME sector enterprises. Various publications have suggested new methods for the measurement of innovative capacity and potential of the enterprises that precisely account for the special character of operations performed and the effect of the regional conditions on the innovativeness of the enterprise (Piech, 2009). New proposals for the measurement of innovative potential very often assume different measurement methods for different sizes of companies (Rosebusch et al., 2009; Martinez-Ros \& Labega, 2002) or groups of companies (e.g., service companies; (Skaalsvik \& Johannessen, 2014; Kaplan \& Norton, 2009; Kanerva et al., 2006) or high-tech companies (Dibrel et al., 2008; Ettlie, 2006; Miles, 2004). At the same time, economists emphasize the strong influence of state regulatory activities in the area of innovation and consequently to increase the competitiveness of the economy (Balcerzak, 2009). 
The Authors of these proposals have indicated that in the implementation of the innovative process in companies belonging to various industries or sectors, there are such great differences that the use of one method of innovative potential measurement very often leads to incorrect results. Such a situation forces one to conduct in-depth studies designed to capture the actual innovative potential of companies.

\section{The Level of Innovativeness of Economy in Brazil and Poland with Particular Emphasis on the SME sector. Overall Assessment}

The innovation theme is treated by the Brazilian government in conjunction with the technology theme, being primarily responsibility of the Ministry of Science, Technology and Innovation (MCTI). MCTI's priorities are to expand and consolidate the National System of Science, Technology and Innovation, promote technological innovation in enterprises, promote research, development and innovation in strategic areas and promote science, technology and innovation for social development.

In order to achieve its main goal, the Ministry, as well as its position as a strategic component of economic and social development of Brazil, the MCTI is structured into four main departments: Department of Policies and Programs of Research and Development, Department of Science and Technology for Social Inclusion, Department of Technological Development and Innovation and Department of Informatics Policy (Brazil. Ministry of Science, 2014).

Among the main sources of funding of MCTI, there is the National Council for Scientific and Technological Development (CNPq) - which fosters scientific and technological research and the training of human resources for research in the country and the Financier of Studies and Projects (FINEP), which promotes and finances innovation and scientific and technological research in companies, universities, technology institutes and research centers.

With regard to performance indicators, Brazil still lacks depth and has no consistent tools. Quoted by the government itself as a task of constant improvement, the indicators used various methodologies congregate manuals used worldwide as: Manual Family Frascatti, Oslo Manual, Manual TBP, Canberra Manual and Manual of Patent. In general, these indicators show the country's position in relation to applied financial and human resources, training grants, scientific production, patent, implementation of 
product innovations and process by Brazilian companies as well as international comparisons.

With this, the best tool that provides an overview of Brazilian companies on the issues related to innovation refers Innovation Research (PINTEC) (see: Brazil. Pintec, 2014) that since 2000 is held every three years by the Brazilian Institute of Geography and Statistics (IBGE) in partnership with the Ministry of Science, Technology and Innovation. The research aims to build national and regional indicators of innovation activities of Brazilian companies. Its focus is on the factors influencing the innovative behavior of firms, the strategies adopted, the efforts, incentives and innovation outcomes.

The IBGE study uses the definition of innovation contained in the Oslo Manual and follows the logic of the questionnaire used by Eurostat, the official statistical agency of the European Commission for the Third Community Innovation Survey. The concept of technological innovation is translated as placing on the market a product (good or service) technologically new or substantially enhanced, or even the adoption by the company of a technologically new or significantly enhanced production process market.

Their results are presented by the sectors of activity and the size of the company, identifying the nature and intensity of innovative activities, the degree of novelty of the changes implemented, the sources of information used and interaction with suppliers or buyers.

The questionnaire used in the survey incorporates the key concepts of innovation economics in its evolutionary aspects. The innovation refers to product and/or new process (or significantly improved) to the firm and are not necessarily new to the market, may have been developed by the company or by another company/institution, and may result from new technological developments, new combinations of existing technology or utilization of other knowledge acquired.

Among the various data collected by the survey, the element which stands out is the rate of innovation of Brazilian firms, which corresponds to the ratio between the number of companies who claim to have introduced at least one innovation in the period considered and the total number of companies in the sectors surveyed by Pintec. Thus, the rate of innovation can be considered a measure of the resulting effort of enterprises to deploy innovations. 
Table 1. Rate of innovation in the extractive industry and manufacturing (19982011)

\begin{tabular}{|c|c|c|c|c|c|}
\hline $\begin{array}{c}\text { Reference } \\
\text { period }\end{array}$ & $\begin{array}{c}\text { Rate of } \\
\text { innova- } \\
\text { tion }\end{array}$ & $\begin{array}{c}\text { Rate of } \\
\text { product } \\
\text { innovation }\end{array}$ & $\begin{array}{c}\text { Rate of innova- } \\
\text { tion of new } \\
\text { products for } \\
\text { the domestic } \\
\text { market }\end{array}$ & $\begin{array}{c}\text { Rate of } \\
\text { process } \\
\text { innovation }\end{array}$ & $\begin{array}{c}\text { Rate of innovation } \\
\text { of new process for } \\
\text { the domestic } \\
\text { market }\end{array}$ \\
\hline $1998-2000$ & $31.52 \%$ & $17.58 \%$ & $4.13 \%$ & $25.22 \%$ & $2.78 \%$ \\
\hline $2001-2003$ & $33.27 \%$ & $20.35 \%$ & $2.73 \%$ & $26.89 \%$ & $1.21 \%$ \\
\hline $2003-2005$ & $33.36 \%$ & $19.53 \%$ & $3.25 \%$ & $26.91 \%$ & $1.66 \%$ \\
\hline $2006-2008$ & $38.11 \%$ & $22.85 \%$ & $4.10 \%$ & $32.10 \%$ & $2.32 \%$ \\
\hline $2009-2011$ & $35.56 \%$ & $17.26 \%$ & $3.66 \%$ & $31.67 \%$ & $2.12 \%$ \\
\hline
\end{tabular}

Source: IBGE (Pintec).

According to the data obtained in the five editions of the survey conducted by IBGE, we observe that, in the last reporting period (2009-2011) occurred for the first time, a decrease in the rate of firms of the manufacturing sector, with a decline from $38.11 \%$ to $35.56 \%$. The global recession of 2009 and the appreciation of the Brazilian currency ( $\mathrm{R} \$$ real) against the U.S. dollar negatively influenced the development and implementation of innovations in enterprises of the country. Moreover, competition from Chinese products also contributed to the stagnation of some Brazilian industrial sectors.

Another important point to note refers to the scope of the Survey of Innovation applied by the IBGE. Among the requirements for participation, it is necessary that the company has ten or more employees, excluding the study, therefore, micro companies with up to 9 employees. Therefore, this research is relevant also for allowing the participation of enterprises with up to 9 employees, since this portion is not represented in official studies and surveys on innovation indicators of the Brazilian government.

Thus, it is verified that officially there is no tool in Brazil to assess comprehensively the effectiveness of innovations implemented by micro enterprises in the country, since the adopted research reaches only a portion of this group. According to a study released in 2011 by the Central Register of Enterprises of IBGE, in 2009 Brazil had 4,309,463 micro enterprises, which represented $88.9 \%$ of establishments registered in the country.

Within the years 2006 - 2013, huge investments have been made in order to increase the innovativeness of the Polish economy. The investments have been implemented in the form of the Operational Programme Innovative Economy (OPIE), financed from the EU funds and from the state funds. The total value of the investments within the framework of the pro- 
gramme was 10.18 billion EUR, including 8.65 billion EUR from the EU budget and the rest from the state funds ${ }^{3}$.

The main objective of the investment was to increase innovation and competitiveness of the Polish economy (Piech, 2007). The main priority within OPIE were actions related to investments in innovative undertaking (15.08 billion PLN), research and development of modern technologies (6.24 billion PLN), infrastructure of research and development area (5.32 billion PLN), information society - increase of the economy's innovativeness (3.84 billion PLN) or diffusion of the innovation (1.82 billion PLN).

According to the situation as for October 2013, within OPIE 13,277 projects have been approved for total amount of 40.15 billion PLN. Such support level is unprecedented in Polish history.

Simultaneously, such a great scale of investments in the innovativeness of the economy forces to perform an extensive analysis and assessment of the undertaken actions. One of the assessment possibilities is the efficiency evaluation in relation to the dynamics of changes in innovative activity of Polish companies. The Authors of this article have focused on the evaluation of the innovative efficiency of SME sector companies.

A series of reports on the innovativeness of the Polish economy has been issued recently (Rybiński, 2011; Hausner, 2012; Baczko, 2012). The reports critically evaluated the innovativeness of the Polish economy and analyzed various aspects of the problem.

The Rybiński's report evaluates nine components influencing the level of Polish economy's innovativeness and reveals that Poland is rapidly losing its distance to other countries in the area of innovativeness.

The Hausner's report elaborates on the weaknesses of the Polish development policy, and reveals the lack of mechanisms stimulating innovativeness. The Hausner's report provides data indicating the low level of Polish economy's innovativeness and points out a series of causes of the situation, among other: the lack of strategic leadership, bureaucratic procedures, identification of the UE funds expenditure with the development policy, low evaluation level of the EU funds expenditure. Similarly, critical opinions are included in the Baczko's report.

Also the reports issued by foreign institutions provide a critical evaluation of the Polish economy's innovativeness level. It may be exemplified with the reports: Union Scoreboard and World Economic Forum.

In the report, the value of the innovativeness index for Poland has dropped from 3.5 to 3.3 within the last six years, and in the global innovativeness ranking Poland went down from position 44 to 66 .

\footnotetext{
${ }^{3}$ Retrived from: www.poig.gov.pl (10.10.2014).
} 
The mentioned reports focus on the whole Polish economy and do not provide a detailed analysis of the innovativeness of SME sector companies.

\section{Methodology of the Research}

The starting point for conducting empirical research was the Authors' hypothesis: (H1) The determinants forming the innovative potential are similar for Brazilian and Polish companies of SME sector.

In order to confirm or negate the hypothesis, the Authors have conducted empirical research of the innovative activities' determinants in the SME sector companies in Brazil and Poland. An Internet questionnaire including 23 questions divided into 8 categories has been used in the research.

The structure of the research tool (questionnaire) is based on the innovativeness audit methodology devised at the University in Hamburg ${ }^{4}$ and used for researching innovative potential of companies. The applied research method is based on the analysis of the innovative processes taking place in companies - with a special consideration of the nature of innovative processes taking place in SME sector companies. The network model of the innovative process, widely described in the modern literature (see Kotsemir \& Meissner, 2013; Graf, 2006; Vahs \& Burmester, 2003) and used in practice, is used by the Authors as the model innovative process - it divides the innovative activity into stages and vividly stresses company's cooperation with the surroundings. The analysis of the process enables indication of eight areas of company's activity which substantially determine the innovative activity. The identified areas covered all the company's innovative activity stages and allowed for the division into external and internal determinants. The following areas of company's operation have been researched in detail:

1. Analysis of the internal and external situations of the company,

2. Issues concerning the search for ideas with regard to innovation,

3. Issues concerning project planning with regard to innovation,

4. Financing of innovative projects,

5. Innovation culture and strategy of human resources development,

6. Company internal communication and its organization,

7. Issues concerning diffusion and transfer of innovation into the market, and

8. Issues concerning implementation of innovative projects.

\footnotetext{
${ }^{4}$ Since 2009 Szczecin University and the University in Hamburg have been implementing partner research considering innovative potential of companies.
} 
The questionnaire was addressed to owners or managers responsible for development and innovative activity in the researched companies. Closedend questions were scaled from 1 to 5 (where 1 - meant the lowest value and 5 - the highest value). Some of the asked questions considered the selfevaluation of the quality of innovative activity, some of them required providing specific numerical and financial data. Obviously, the Authors are aware that the self-evaluation may be of subjective nature, and it makes the generalization of the conclusions more complicated - however in case of the majority of quality information this method of collecting information seams to by the only option.

Preparing a research tool and a range of research, Authors conduced a detailed review of global research in the field of innovation potential and drew upon the experience of other Authors. In particular, the Authors took into account the results of research carried out by Miller (1983, pp. 770791) and Zahra \& Wicklund (2010; research on the level of innovation), Koberg et al. (2003, pp. 21-45; research on communication in organizations), Cameron \& Quinn (2003; research on organizational culture). During the preparation of a research tool, the Authors used the achievements of Polish researchers: Zastępowski (2010, Conditions for building the innovation potential of Polish small and medium-sized enterprises) and MazurekKucharska et al. (2008, Social determinants of innovation of enterprises). Detailed methodology and the full scope of the study are described in other publications (Norek 2011).

The received results have been subject to basic statistical analysis, and on this basis with the logical induction the Authors have made conclusions on the determinants of innovative activity in researched companies.

In case of SME sector companies in Brazil, the research was of pilot nature and addressed only a small number of companies. The Authors are fully aware that such a small number of the researched companies is not representative of the whole SME sector in Brazil, and does not give grounds for general conclusions. Nevertheless, the conducted research provides initial picture if the determinants forming innovativeness and enables making deeply basic conclusion and provide an answer to the question considering the validity of conduction further research of the area.

The target population of this study were Brazilian companies from the Software and Services sector linked to the Brazilian Association of Software Companies (ABES). The choice of this population occurred because it refers to a sector focused on innovation.

First, the Authors contacted the ABES and requested permission to apply the research with directors and managers of associated companies. After approval, the questionnaire was elaborated in an online platform and its 
link was published on the association page, including a brief explanation of the study and an invitation to participate. The disclosure occurred in early December 2013 and the results were awaited by mid-January 2014. Only 36 valid responses were received: 6 of Software Companies (16.66\%), 28 of Software and Services Companies (77.78\%) and 2 Companies of Hardware, Software and Services $(5.56 \%)$.

Regarding the classification of companies, the Authors adopted the definition used by the Brazilian Institute of Geography and Statistics (IBGE) and the Brazilian Support Service for Micro and Small Enterprises (Sebrae), which uses based on the number of employees: 0-19 - micro enterprise; 20-99 - small enterprise; 100-499 - medium enterprise; 500 or more - great company. So, the division in this study was as follows: 16 micro enterprises, 14 small enterprises and 6 medium enterprises. Terms of geographical distribution, 3 companies are located in the Midwest of the country, 2 companies in the Northeast, 25 companies in the Southeast and 6 companies in southern Brazil.

In Poland 200 companies from three regions were selected for the analysis: Zachodniopomorskie - medium innovation performance voivodship, Podkarpackie - low innovation performance voivodship, Mazowieckie - high innovation performance voivodship.

Table 2. Structure of the research sample

\begin{tabular}{|l|c|c|c|c|c|}
\hline $\begin{array}{c}\text { Size of the } \\
\text { companies }\end{array}$ & $\begin{array}{c}\text { Brazilian } \\
\text { sample }\end{array}$ & \% Brazil & $\begin{array}{c}\text { Polish } \\
\text { sample }\end{array}$ & \% Poland & Total \% \\
\hline Micro & 16 & $44.44 \%$ & 79 & $39.50 \%$ & $40.25 \%$ \\
\hline Small & 14 & $38.89 \%$ & 94 & $47.00 \%$ & $45.76 \%$ \\
\hline Medium & 6 & $16.67 \%$ & 27 & $13.50 \%$ & $13.98 \%$ \\
\hline SUM & 36 & $100.00 \%$ & 200 & $100.00 \%$ & $100.00 \%$ \\
\hline
\end{tabular}

Source: own elaboration.

They were selected in a purposeful manner to ensure an appropriate research structure: $45 \%$ of production companies, $55 \%$ of service companies. The division, due to the size of the examined companies, was as follows: $39 \%$ micro enterprises, $47 \%$ small enterprises, $13 \%$ medium enterprises. The sample for comparative research was standardized with statistical methods taking into consideration the structure of individual provinces' economy: size of the company and dominant type of the conducted activity. The Authors are fully aware that the analyzed sample is not representative, however it is an amount sufficient to perform the analysis and make con- 
clusions. The research was conducted during the period from April 2013 to August 2013. Structure of the research sample is presented in Table 2.

\section{Comparison of Determinants of Innovative Activity of SMEs in Brazil and Poland}

On the basis of the conducted research of the eight (described above) areas of the innovative activity, the Authors have calculated an average indicator describing innovative activity of the researched companies. For the MSE sector companies in Brazil the indicator was 3.735 and for the Polish companies it was 3.487. The companies of the SME sector in Brazil reveal far bigger, in broad sense, innovative culture in relation to Polish companies (the difference of the results for the area is 0.9). It seems that the aspect is directly transferred to (related with) a better internal communication of Brazilian companies (difference is 0.99), project planning (difference is 0.2 ) and as consequence it results in better general implementation of innovative projects (difference is 0.29 ).

Polish companies reveal greater abilities of financing innovative activity (difference is 0.14 ) which is related to a great possibility of financing innovative projects with the EU funds.

The remaining research areas reveal similar results for Brazilian and Polish companies - difference around 0.1. Despite the above-mentioned differences, the results may be considered similar (unimportant differences) and confirming the proposed research thesis.

Table 3 presents the means grouped by categories, according to the research design.

Table 3. Aggregate Values for Innovation Capacity of Surveyed Enterprises

\begin{tabular}{|c|l|c|c|c|}
\hline \multirow{2}{*}{$\mathrm{N}$} & \multicolumn{1}{|c|}{ Categories } & \multicolumn{2}{c|}{ Mean of category } & Issues in \\
\cline { 3 - 4 } & & Brazil & Polish & $\begin{array}{c}\text { each } \\
\text { category }\end{array}$ \\
\hline 1 & Analysis of internal and external situation of the company & 3.90 & 4.0 & 3 \\
\hline 2 & The search for innovative ideas & 3.77 & 3.8 & 4 \\
\hline 3 & Planning projects regard to innovation & 3.70 & 3.5 & 3 \\
\hline 4 & Financing of innovative projects & 3.36 & 3.5 & 3 \\
\hline 5 & Innovative culture & 3.80 & 2.9 & 3 \\
\hline 6 & Internal communication & 3.99 & 3.0 & 2 \\
\hline 7 & Control, diffusion and transferring innovation & 3.67 & 3.8 & 3 \\
\hline 8 & Implementation of innovative projects & 3.69 & 3.4 & 2 \\
\hline
\end{tabular}

Source: own elaboration. 
Analysis of the internal and external situations of the company

As regards internal and external analysis, firms were asked if they took into consideration the market incentives to develop new products or services, if they had the ability to expand the company and if they worked in cooperation or partnership with institutions to support the implementation of new innovative projects. The highest average was verified in the account related to external stimuli item (Brazil $\mathrm{M}=4.22$, Poland $\mathrm{M}=4.37$ ), demonstrating that the companies surveyed are concerned and alert to the market, the competition and the public incentives when developing new innovative products or services. The possibility of expanding the activities resulting from the introduction of new products is also significant - it received higher mean (Brazil $\mathrm{M}=4.00$ Poland $\mathrm{M}=4.1$ ). The lowest average was related to work in cooperation with institutions or companies (Brazil $\mathrm{M}=3.50$, Poland $\mathrm{M}=3.72$ ), demonstrating that most of the SMEs surveyed do not develop joint projects, which could leverage their business and increase their innovative capacity.

\section{The search for innovative ideas}

In this topic, respondents were asked if the opinion of customers and employees was important for the development of new products, if the company usually hire market research or experts in innovation and if the company had an established channel for collecting opinions of customers and employees. The highest average was observed in the importance that MSEs attach to opinions from customers to develop new products (Brazil M $=4.33$, Poland $\mathrm{M}=4.35$ ) demonstrating a market-driven orientation. Was also high for the average found related to employee opinion item (Brazil M $=4.19$; Poland $\mathrm{M}=4.25$ ), demonstrating that the owners are attentive to the team. Relating the formal channels for collection of opinion, the average was not significant (Brazil $\mathrm{M}=3.30$, Poland $\mathrm{M}=3.31$ ). This finding indicates that the collection of feedback from clients and employees usually occurs informally in much of the SMEs. The companies surveyed also said they usually do not use market research or opinion of external experts in the search for new ideas ( $M=3.27$, Poland $M=3.29)$. This can be explained by the lack of resources of the enterprise, because this kind of assistance requires investments that most businesses do not have. 


\section{Planning projects regard to innovation}

Related to planning, was asked if SMEs have the capacity and knowledge to evaluate new ideas, if they have criteria for knowing when to continue and when to stop the development of new ideas, and have a formal management process related to the development of new products or services. The highest mean was observed in the capacity of MSEs to assess the potential of new ideas (Brazil $\mathrm{M}=4.80$, Poland $\mathrm{M}=4.78$ ). In this sense, it is possible to attest that respondents consider themselves to possess the knowledge sufficient for decision-making on issues related to the development of an innovative idea. However, the item related to the definition of criteria to decide when to stop or when to continue to develop an innovative product or service, received low values (Brazil $\mathrm{M}=3.52$, Poland $\mathrm{M}=2.24$ ). The mean related to the existence of a formal process for managing issues related to innovation nor obtain a satisfactory average too (Brazil $\mathrm{M}=3.50$, Poland $\mathrm{M}=3.48$ ). This indicates that, although most of the respondents declares that their company has the ability to assess the potential of new ideas, this evaluation does not occur in a formal manner, to previously established criteria, but informally, according to the evaluation of the owner.

\section{Financing of innovative projects}

Regarding funding of innovative projects, the means obtained were not significant. SMEs were questioned if they had resources available for innovative projects, if they had ways to assess the availability of resources and if the company had empowered people to obtain resources. Regarding the availability of resources, it appears that most SMEs do not have the financial capacity for new projects (Brazil $\mathrm{M}=3.33$, Poland $\mathrm{M}=3.52$ ), and maybe this is the most difficult for business growth. Also, it was observed that part of the companies surveyed do not have the people qualified to evaluate the need for resources in an innovative new project (Brazil $\mathrm{M}=3.50$, Poland $\mathrm{M}=3.62$ ), corroborating what was previously observed, about the lack of criteria to evaluate the viability of the one new project. Finally, the existence of qualified people to find funds in the market, the average calculated was even lower (Brazil $M=3.25$, Poland $M=3.50$ ), demonstrating that the MSEs surveyed do not have sufficient resources to the development of innovative ideas and find it difficult to obtain funds financial market because of lack of qualified people, which undermines their business in the medium and long term. 


\section{Innovative culture}

In this topic, we aimed to verify that the innovative profile is disseminated in corporate culture, by questioning participants about the clarity of the owners in the disposition to innovate (on the top), the willingness to take risks in implementing innovative projects and whether or not there was recognition for those employees who contribute to the implementation of innovative ideas. Regarding the willingness to innovate starting with the owners and directors, the mean was not very high (Brazil $\mathrm{M}=3.83$, Poland $M=2.7$ ), suggesting that not all owners of SMEs participants are aware of their responsibility for the development and effectiveness of innovative actions in their companies. On the other hand, the willingness to take risks appears to be present in most of the participating companies (Brazil M $=4.04$, Polish $\mathrm{M}=3.2$ ), demonstrating that they know the importance of taking risks for the implementation of innovative projects. The lowest mean value for this topic has been verified in recognition to employees (Brazil M $=3.52$, Polish $\mathrm{M}=2.8$ ). According to the data collected, is not yet entrenched in the companies the need to reward and gratify employees who collaborate and contribute with innovative practices. This makes the staff not engaging with motivation to projects presented and its performance may be lower than expected.

\section{Internal communication}

The effectiveness of internal communication was assessed through questions regarding the use or not of technological tools to support communication and beliefs of respondents regarding efficiency and effectiveness in providing the information to company employees. On the first question, the mean was Brazil $\mathrm{M}=4.11$, Poland $\mathrm{M}=3.0$ demonstrating that most SMEs use of support and teamwork tools.

The Authors conclude that in the case of Brazilian companies, the result is determined by the fact that the study involved software producing companies - for which the use of modern communication tools is more natural. However, the in case of the issues related to efficiency and effectiveness in the transmission and flow of this information, the average calculated was not as significant (Brazil $\mathrm{M}=3.88$, Poland $\mathrm{M}=3.04$ ). Whereas the research was conducted with micro, small and medium enterprise, the efficiency and effectiveness in internal communications proved to be lower than expected, because the number of employees and hierarchical levels in these companies is reduced. 


\section{Control, diffusion and transferring innovation}

The purpose of this item was to verify the control that SMEs have the number of products/services implemented and your profitability, as well as the acceptance of its products in the market. The average found about to the control the number of innovative products implemented in recent months and/or years was Brazil $M=3.88$, Poland $M=3.95$. This suggests that some SMEs do not have control of what they produce, which certainly hinders the planning of goals to be achieved. Consequently, the mean is even lower in the matter relating to the control of the profitability of the products introduced in the market (Brazil $\mathrm{M}=3.61$, Poland $\mathrm{M}=3.85$ ), demonstrating the fragility of SMEs in matters relating to financial control of costs, expenses and profits obtained from the business. The evaluation of the acceptance of their products in the market is also unrealized for a share of the companies surveyed (Brazil $\mathrm{M}=3.52$, Poland $\mathrm{M}=3.72$ ). Thus, they fail to improve their products/services and customer loyalty, hindering the company's earnings over the long term.

\section{Implementation of innovative projects}

Finally, the topic related the implementation of innovative products/services aimed to identify whether the participating companies have quality monitoring and costs monitoring of what they put on the market and if they are alert to the training of employees who work directly with the products launched. The first item, related to the existence of monitoring systems of quality control and cost control of all innovative products implemented, the average was low (Brazil $\mathrm{M}=3.38$, Poland $\mathrm{M}=3.21$ ), confirming the values of the previous topic. Again, we see the difficulty that companies find to monitor and measure the results of what they produce and offer to customers. Regarding the preoccupation of SMEs with training and knowledge's people directly involved in the presentation and marketing of new products/services, the value verified was Brazil $\mathrm{M}=4.00$ and Poland $=3.59$. Considering the average calculated in the other research questions, it can be affirmed that the results found in this item is positive, making us believe that the companies surveyed are attentive to the training of those who implement their innovative products/services.

Graphical comparison of the results (clearly illustrating the differences) is shown in Chart 1. 
Figure 1. Aggregate Values for Innovation Capacity of Surveyed Enterprises

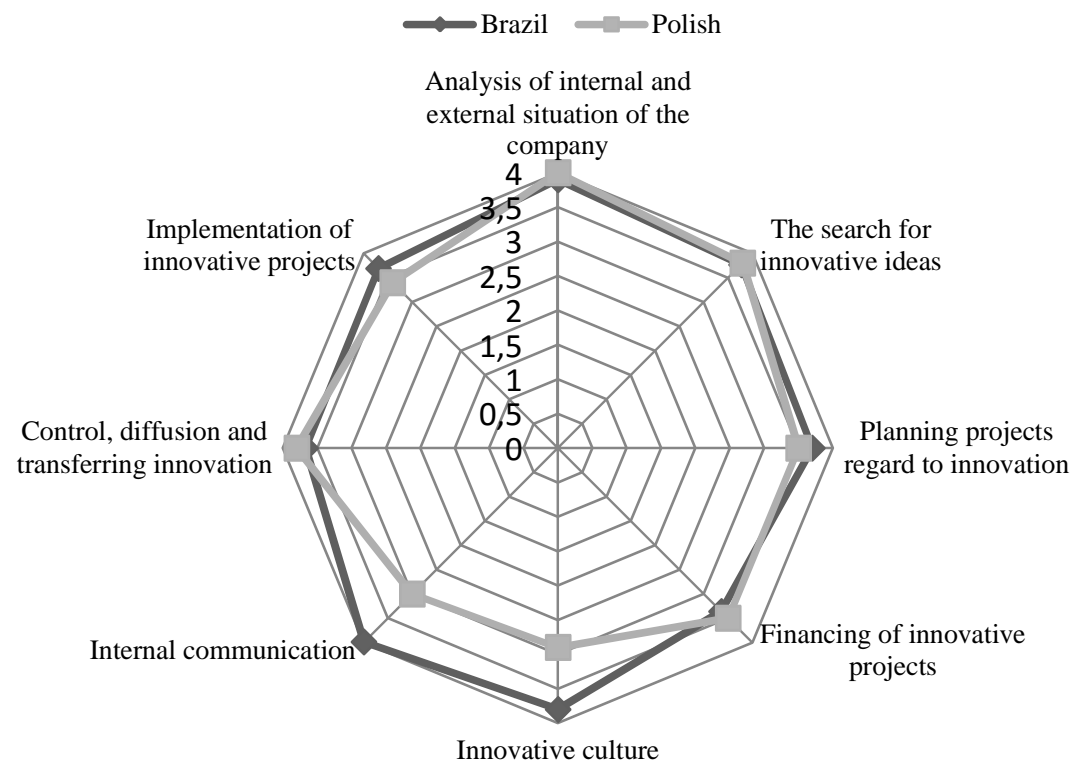

Source: own calculations.

\section{Conclusions}

The obtained results enable the confirmation of the thesis put forward by the Authors - determinants forming the innovative potential are similar for Brazilian and Polish companies of SME sector. The average indicator describing innovative activity of the researched companies was slightly bigger for Brazilian companies (the difference is 0.247) - but the difference may be considered small.

Regarding Brazil, although the research findings can not be generalized - because of the small number of participants, they reflect the scenario of most micro, small and medium enterprises in the country. Actions related to the search for innovation activities are not yet part of the day-to-day SMEs According to a ranking prepared by the World Intellectual Property Organization (WIPO) ${ }^{5}$, Brazil ranked only 64th in the Global Innovation

\footnotetext{
${ }^{5}$ World Intellectual Property Organization, "Global Innovation Index 2013", 2014. Retrieved from: http://www.globalinnovationindex.org/content.aspx?page=data-analysis
} 
Index 2013, out of the total of 142 participating nations - an uncomfortable position, considering the country's potential.

With specific regard to this research, the results point to the financing of innovative projects as the major difficulty for the effectiveness of actions related to innovation. The lack of resources and lack of people qualified for raising these funds in the market undermines the development of new products and new processes in SMEs. Another important factor relates to the lack of control of companies as the number of deployed products, the profitability of these products as well as their level of market acceptance. Without this control, it is difficult for them to conduct planning and decision making for the future, because they can not assess the current situation and the company's market position.

On the other hand, there were good averages on the issues related to internal communication and analysis of internal and external situation of the company, indicating that technological tools have been used effectively and that the SMEs surveyed are attentive to the environment to which they are inserted. Individually, we highlight the importance of SMEs attach to the opinion of customers to develop new products/services, as well as the importance to external stimuli, such as competition and market.

Even though the results are below the desired level, Brazil has advanced significantly in the dissemination of subject matter and discussing issues related to innovation. In the public sphere, large amounts of funds are allocated each year to innovative projects - in its majority managed by the Ministry of Science, Technology and Innovation. In the business field, organs such as the Brazilian Service of Support for Micro and Small Enterprises (Sebrae) and the National Confederation of Industry (CNI) invest in the promotion of lectures, courses and training that guide and stimulate innovative practices. In universities, a growing number of research and models developed on the subject. The challenge, however, lies in uniting these forces and turn their efforts into practical results, which mainly improve the activities of SMEs of the country.

The conducted research enabled forming recommendations for further research. It seems that the obtained results should be subject to a detailed statistical and economic analysis (the applied research tool - questionnaire - was designed in such way as to provide multidimensional data enabling the analysis of innovative activities in the researched companies in various sections. Such research could result in defining the importance of the influence of individual determinants on the innovative activities in the researched companies and undertaking an attempt at the construction of models describing ways of implementing innovative activities by the SME sector companies. Such research have already been conducted for Polish 
companies. The Author (Norek, 2013) has presented the results at several international conferences and published them in a series of scientific publications.

Another recommendation concerns undertaking of an effort to continuously monitor the dynamics of changes of innovative activity determinants in the researched companies. Such research may reveal trends in the innovative activity of the SME sector companies and provide arguments for creating regional innovative policy. The Author (Norek, 2012) has been conducting continuous research of the dynamics of innovative activity in the SME sector companies in Poland since 2009. The results of the research have also been presented and published many times.

\section{References}

Acedo, F., \& Florin, J. (2006). An entrepreneurial cognition perspective on the internationalization of SMEs. Journal of International Entrepreneurship, 4(1).

Audretsch, D. (2001). Research issues relating to structure, competition, and performance of small technology-based firms. Small Business Economics, 16(1).

Baczko T (ed.). (2012). Raport o innowacyjności polskiej gospodarki w 2011 roku. Warszawa: INE PAN

Balcerzak, A. P. (2009). Wpływ działalności regulacyjnej państwa w obszarze kreowania ładu konkurencyjnego na rozwój nowej gospodarki. In A. P. Balcerzak (Ed.). Aktywność regulacyjna państwa a potencjał rozwojowy gospodarki. Toruń: Polskie Towarzystwo Ekonomiczne Oddział w Toruniu.

Białoń, L. (Ed.). (2010). Zarządzanie działalnością innowacyjną. Warszawa: Placet.

Birchall, D. W., \& Armstrong, M. S. (2001). Innovation Management. Achieving Multiple Objectives. Henley Management College. http://dx.doi.org/10.1109/ PICMET.2003.1222782.

Bloch, C. (2005). Innovation measurement: present and future challenges. Working paper from The Danish Centre for Studies in Research and Research Policy 2005/6.

Brazil. Ministry of Science. Technology and Innovation, Estrutura (2014). Retrieved from: http:// www.mcti.gov.br/index.php/content/view/105.html ?execview $=$.

Brazil. Pintec, Pesquisa de inovação (2014). Retrieved from: http://www.pintec.ibge.gov.br/index.php?option=com_content_extjs\&view=art icle\&id $=17 \&$ Itemid $=6$.

Cameron, K. S., \& Quinn, R. E., (2003). Kultura organizacyjna - diagnoza i zmiana. Model wartości konkurujących. Kraków: Oficyna Ekonomiczna.

Chmiel, J. (2007). Raport o stanie sektora MSP w Polsce w latach 2005-2006. Warszawa: PARP. 
Cooke, P.(ed.). (2011). Handbook of Regional Innovation and Growth. Cheltenham: Edward Elgar Publishing Limited. http://dx.doi.org/10.4337/97808 57931504.

Dibrell, C., Davis, P., \& Craig, J. (2008). Fuelling innovation through information technology in SMEs. Journal of Small Business Management, 46(2).

Ettlie, J. E. (2006). Managing Innovation, Butterworth-Heineman, an imprint of Elsevier.

Fagerberg, J. (2004). Innovation: A Guide to the Literature. In J. Fagerberg, D. C. Mowery, R. R. Nelson. The Oxford Handbook of Innovations. Oxford: Oxford University Press.

Freel, M. (2003). Sectoral patterns of small firm innovation, networking and proximity. Research Policy, 32(3) http://dx.doi.org/10.1016/S0048-7333(02)00084$\underline{7}$

Gloet, M., \& Samson, D. (2013). Knowledge Management to Support Systematic Innovation Capability. Retrieved from: http://www.hicss.hawaii.edu/hi css_46/bp46/ks4.pdf (08.11.2014), http://dx.doi.org/10.1109/HICSS.2013.374.

Graf, $\bar{H}$. (2006). Networks in the Innovation Process: Local and Regional Interactions, Edward Elgar Publishing Inc.

Hall, B. H., \& Rosenberg, N. (2010). Economics of Innovation, Elsevier

Hausner, J. (2012). Kurs na innowacje. Jak wyprowadzić Polske z rozwojowego dryfu. Kraków: raport Fundacji Gospodarki i Administracji Publicznej, http://dx.doi.org/10.1093/oxfordhb/9780199286805.001.0001.

Janasz, W., \& Kozioł, K. (2007). Determinanty działalności innowacyjnej przedsiębiorstw. Warszawa: PWE.

Jasiński, A. (2004). Innovation performance and public policy in transition: the Polish perspective. International Journal of Technology and Globalization, 1(1).

Kanerva, M., Hollanders, H. \& Arundel, A. (2006). Can We Measure and Compare Innovation in Services? Maastricht: MERIT Maastricht Economic Research Institute on Innovation and Technology.

Kaplan, R. S., \& Norton, D. P. (2009). Wdrażanie strategii dla osiagnięcia przewagi konkurencyjnej. Warszawa: PWN.

Karaganni, S., \& Labriandis, L. (2001). The pros and cons of SME going international. Eastern European Economics, 39(2).

Koberg, C. S., Detienne, D. R. \& Heppard, K. A. (2003). An Empirical Test of Environmental, Organizational and Process Factors Affecting Incremental and Radical Innovation. Journal of High Technolgy Management Research, 14.

Kotsemir, M., \& Meissner, D. (2013). Conceptualizing the innovation process - trands and outlook, Working Paper, Moscow: National Research University Higher School of Economics.

Lager, T., (2011). Managing Process Innovation, From Idea Generation to Implementation. London: Imperial College Press. http://dx.doi.org/10.1142/p734. 
Lituchy, T., \& Rail, A. (2000). Bed and breakfasts, Small Inns, and the Internet: The impact of technology on the globalization of small businesses. Journal of International Marketing, 8(2), http://dx.doi.org/10.1509/jimk.8.2.86.19625.

Low, D., \& Chapman, R. (2007). Inter-relationships between innovation and market orientation of SMEs. Management Research News, 30(12), http://dx.doi.org /10.1108/01409170710833321.

Mangiarotti, G., \& Mention, A. (2014). Investigating firm-level effects of knowledge management strategies on innovation performance. International Journal of Innovation Mamagement, 18(5), http://dx.doi.org/10.1142/S13639 19615500127.

Martinez-Ros, E., \& J. M. Labega J. M. (2002). The Relationship Between Firm Size and Innovation Activity: A Double Decision Approach. Economics of Innovation and New Technology, 11(1), http://dx.doi.org/10.1080/1043859 $\underline{0210894 .}$

Mazurek-Kucharska, B., Block, A. \& Wojtczuk-Turek, A. (2008). Społeczne determinanty innowacyjności przedsiębiorstw, Raport z badania. Warszawa: Pentor International Research.

McCosh, A., Smart, A. Barrer, P. \& Lloyd, A. (1998). Proven Methods for Innovation Management: An Executive Wish List. Creativity and Innovation Management, 7.

McKeown, M. (2008). The Truth About Innovation. Prentice Hall.

Miles, I. (2004). Innovation in Services, In J. Fagerberg, D.C. Mowery, \& R.R. Nelson (Eds.), The Oxford Handbook of Innovations. Oxford: Oxford University Press. http://dx.doi.org/10.1093/oxfordhb/9780199286805.003.0016.

Miller, D. (1983). The Correlates of Entrepreneurship in Tree Types of Firms. Management Science, 29(7).

Norek, T. (2011). Problems of SME Sector Enterprise Innovative Capacity Measurement. In S. Hittmar (Ed.). Theory of Management, The Selected Problems for the Development Support of Management Knowledge Base. Zilina: University of Zilina.

Norek, T. (2013). Key barriers to the development of effective innovative activity of Polish SME companies. The relationship between the company's internal resources and the effectiveness of innovative activity. Business \& Economics Society International, Conference January, Perth Australia.

Norek, T. (2010). Benchmarking innowacyjności przedsiębiorstw w regionie zachodniopomorski. In L. Woźniak (Ed.). Entrepreneurship, Innovation, Foresight: Aspects of Economic, Social and Ecological. Rzeszów: Wydawnictwo Politechniki Rzeszowskiej.

Norek, T., (2012). The Impact of the Innovative Potential of Polish SME Companies on their Innovative Activity Realization Models. GSTF Journal on Business Review, 1(4).

Piech, K. (2007). Knowledge and innovation processes in Central and Eastern Europe. Warszawa: Instytut Wiedzy i Innowacji.

Piech, K. (2009). Wiedza i innowacje $w$ rozwoju gospodarczym: $w$ kierunku pomiaru i wspótczesnej roli państwa, Warszawa: Instytut Wiedzy i Innowacji. 
Poznańska, K. (1998). Uwarunkowania innowacji w matych i średnich przedsiębiorstwach. Warszawa: Dom Wydawniczy ABC.

Prahalad, C. K., \& Krishnan, M. S. (2010). Nowa era innowacji. Warszawa: PWN.

Pro Inno Europe, Innovation Union Scoreboard 2014: Comparative Analysis of Innovation Performance" (2014a). Retrieved from http://www.proinnoeurope.eu/inno-metrics/page/innovation-union-scoreboard-2014.

Pro Inno Europe, Summary Innovation Index (2014b). Retrieved from: http://www.proinno-europe.eu/page/summary-innovation-index-0\#_ftn2.

Rosebusch, N., Brinckmann, J., \& Bausch, A. (2009). Is New Better? A metaAnalysis of Innovation Performance Relationship in SME. Chicago: American Academy of Management Conference,.

Rybiński, K. (2011). Go Global! Raport o innowacjności polskiej gospodarki. Warszawa: Uczelnia Vistula.

Salvato, C., Lassini, U. \& Wiklund, J. (2007). Dynamics of external growth in SMEs: Process of model acquisition capabilities emergence. Schmalebach Business Review, 59(3).

Skaalsvik, H. \& Johannessen J. (2014). Service innovation: suggesting a typology of service innovation. Problems and Perspektives in Management, 12(3).

Tidd, J. \& Bessant, J. (2011). Zarzadzanie innowacjami, Integracja zmian technologicznych, rynkowych i organizacyjnych. Warszawa: Wolters Kluwer Business.

Vahs, D., \& Burmester, R. (2003). Innovationsmanagement, Von der Produktidee zur erfolgreichen Vermarktung. Stuttgart: Schäffer Poeschel.

World Intellectual Property Organization, Global Innovation Index 2013, 2014. Retrieved from: http://www.globalinnovationindex.org/content.aspx?pa ge $=$ data-analysis.

Zahra, S. A., \& Wiklund, J. (2010). Top Management Team Characteristics and New Ventures' Product Innovation. Montreal: paper presented at the American Academy of Management Conference, August.

Zastępowski, M. (2010). Conditions for building the innovation potential of polish small and medium-sized enterprises. Torun: Wydawnicto Naukowe UMK.

Żołnierski, A. (2005). Potencjat innowacyjny polskich matych i średniej wielkości przedsiębiorstw. Warszawa: PARP. 